\title{
Characteristics of Two Unrecorded Yeasts from Wild Flowers in Ulleungdo, Korea
}

\author{
Se-Hee Hyun', Jin-Hong Min', Hyang Burm Lee', Ha-Kun Kim' and Jong-Soo Lee ${ }^{1 *}$ \\ ${ }^{1}$ Department of Biomedicinal Science and Biotechnology, Paichai University, Daejeon 302-735, Korea \\ ${ }^{2}$ Division of Applied Bioscience and Biotechnology, Chonnam National University, Gwangju 500-757, Korea
}

\begin{abstract}
Two unrecorded yeasts, Meyerozyma caribbica UL5-1 and Pichia silvicola UL6-1 were screened from 58 yeasts which were isolated from wild flowers in Ulleungdo in Gyeongsangbuk-do, Korea. The morphological and cultural characteristics of these unrecorded yeasts were investigated. Both yeasts were oval in shape and formed pseudomycelia. P. silvicola UL6-1 formed ascospore, but M. UL5-1 did not. P. silvicola UL6-1 and M. caribbica UL5-1 also grew in vitamin-free medium and 5\% NaClcontaining yeast extract-peptone-dextrose medium. The two unrecorded yeasts assimilated glucose, galactose, xylose, cellobiose, trehalose, glycerol and sorbitol, and also fermented glucose, fructose and mannose. The supernatant of both M. caribbica UL5-1 and P. silvicola UL6-1 showed high antihypertensive angiotensin I-converting enzyme inhibitory activity of $84.2 \%$ and $82.6 \%$, respectively. Cell-free extract of $P$. silvicola UL6-1 also showed very high anti-diabetic $\alpha$-glucosidase inhibitory activity (85.8\%).
\end{abstract}

KEYWORDS : Characteristics, Ulleungdo, Unrecorded yeasts, Wild flowers

Yeast produce various bioactive agents [1-4] including an antihypertensive angiotensin I-converting enzyme inhibitor [5]. Most of the yeasts that produce these compounds have been isolated from fermented foods or their raw materials [3,4,6]. Recently, we isolated and identified various yeasts, including unrecorded yeasts, from wild flowers growing in cities [7,8], mountains [9], inland and coastal areas [10,11], and, islands, such as Jeju Island, Korea [12,13].

In a previous paper [13], we reported the diversity of yeasts present on wild flowers in Ulleungdo and Yokjido, Korea; we also reported other characteristics of the unrecorded yeasts isolated from Yokjido [14]. Here, we describe the mycological characteristics of the unrecorded yeasts isolated from Ulleungdo, Korea.

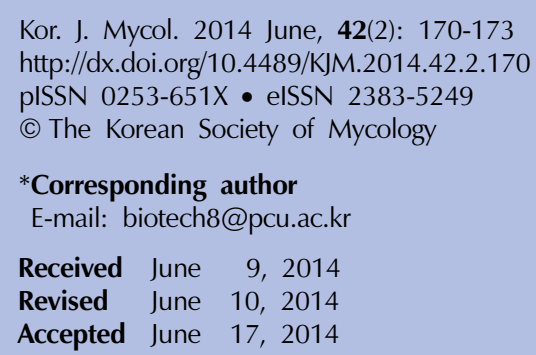

@This is an Open Access article distributed under the terms of the Creative Commons Attribution Non-Commercial License (http:// creativecommons.org/licenses/by-nc/3.0/) which permits unrestricted non-commercial use, distribution, and reproduction in any medium, provided the original work is properly cited.
We investigated the morphological characteristics of the unrecorded yeasts using previously described methods [13]. The physiological functions of the yeasts were determined as follows. The selected unrecorded yeasts were cultured in yeast extract-peptone-dextrose (YPD) medium at $30^{\circ} \mathrm{C}$ for $2 \mathrm{~d}$. After centrifugation at $10,000 \times \mathrm{g}$ for $15 \mathrm{~min}$, supernatants and cells were obtained. The cells were disrupted by vortexing with sonication and then centrifuged at $12,000 \times \mathrm{g}$ for $20 \mathrm{~min}$. Cell-free extract was obtained and the supernatant was used to determine the physiological functionalities of the yeasts.

Antihypertensive angiotensin I-converting enzyme (ACE) inhibitory activity was assayed using the method published by Cushman and Cheung [15]. Antioxidant activity was assayed using the method of Lee et al. [4] using antioxidant activity (DPPH) as a substrate. Tyrosinase inhibitory activity was assayed by the method of Kim et al. [16]. Xanthine oxidase inhibitory activity and superoxide dismutase (SOD)-like activity were determined using a modification of a previously described method [9]. $\alpha$ Glucosidase inhibitory activity was assayed using the method described Kang et al. [17] using $\rho$-nitrophenyl- $\beta$-Dglucophylanoside (PNPG) as a substrate.

The unrecorded yeasts were screened from 58 yeasts isolated in Ulleungdo by searching Keris, PubMed and other fungal taxonomy databases. The previously unrecorded yeasts were identified as Meyerozyma caribbica UL 
Table 1. Microbiological and cultural characteristics of the newly reporting yeasts from wild flowers of Ulleungdo, Korea

\begin{tabular}{lcc}
\hline \hline & $\begin{array}{c}\text { Meyerozyma } \\
\text { caribbica } \\
\text { UL5-1 }\end{array}$ & $\begin{array}{c}\text { Pichia } \\
\text { silvicola } \\
\text { UL6-1 }\end{array}$ \\
\hline Morphological characteristics & $\mathrm{O}^{1)}$ & $\mathrm{O}$ \\
Shape & $\mathrm{B}^{2)}$ & $\mathrm{B}$ \\
Vegetalle reproduction & $2.6 \times 2$ & $3.4 \times 2.6$ \\
Size $(\mu \mathrm{m})$ & - & + \\
Ascospore & + & + \\
Pseudomycelium & ++ & +++ \\
\hline Cultural and physiological characteristics & & +++ \\
Growth on YM & +++ & +++ \\
Growth on YPD & ++ & $\mathrm{W}$ \\
Growth on PD & $\mathrm{W}^{3)}$ & ++ \\
Color on YPD & ++ & - \\
Growth on Vitamin-free medium & + & + \\
Growth in $50 \%$ Glucose-YPD & ++ & - \\
Growth in $5 \% \mathrm{NaCl}-\mathrm{YPD}$ & + & $20-30^{\circ} \mathrm{C} /$ \\
Growth in $20 \% \mathrm{NaCl}-\mathrm{YPD}$ & $25-37^{\circ} \mathrm{C} /$ \\
Groth in temp. / pH range & $4-5$ & $4-8$ \\
Urease activity & - & - \\
\hline
\end{tabular}

${ }^{11} \mathrm{O}$, Oval ${ }^{2)} \mathrm{B}$, Budding ${ }^{3)} \mathrm{W}$, White

A

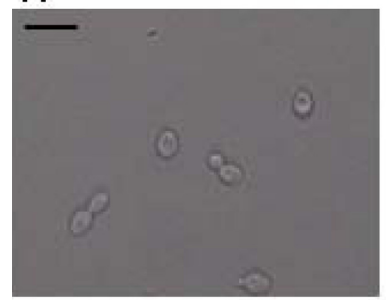

$\mathrm{C}$

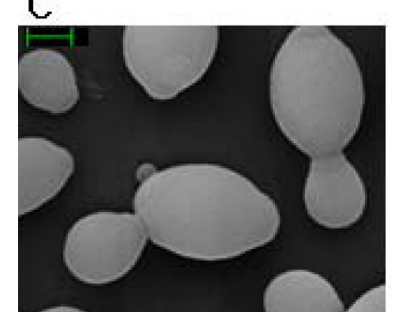

Fig. 1. Morphological characterization of Meyerozyma caribbica UL5-1 (A,C) and Pichia silvicola UL6-1 (B,D). A and B, Optical microscope (scale bar-1 $\mu \mathrm{m}$ ); C and D, Scanning electron microscope (scale bars $=5 \mu \mathrm{m})$.

5-1 and Pichia silvicola UL6-1; they were isolated from Duchesnea chrysantha and Rubia akane in Ulleungdo.
Table 2. Comparison of carbon sources assimilaion between Meyerozyma caribbica UL5-1 and Pichia silvicola UL6-1

\begin{tabular}{lcc}
\hline \hline & $\begin{array}{c}\text { Meyerozyma } \\
\text { caribbica } \\
\text { UL5-1 }\end{array}$ & $\begin{array}{c}\text { Pichia } \\
\text { silvicola } \\
\text { UL6-1 }\end{array}$ \\
\hline D-glucose & $+^{*}$ & + \\
D-galactose & + & + \\
L-arabinose & + & - \\
D-xylose & + & + \\
D-cellobiose & + & + \\
D-lactose & - & - \\
D-saccharose & + & - \\
D-trehalose & + & + \\
D-maltose & + & - \\
N-acetyl-glucosamine & + & - \\
D-melezitose & + & - \\
D-raffinose & + & - \\
Methyl- $\alpha-D$-glucopyranoside & + & - \\
2-keto-D-gluconate & + & - \\
Glycerol & + & + \\
Adonitol & + & - \\
Inositol & - & + \\
D-sorbitol & + & - \\
Xylitol & + & + \\
${ }^{*}+$ Growth(assimilation), -; No growth(no assimilation) & \\
& & + \\
\hline
\end{tabular}

Table 3. Comparison of carbon sources fermentation between Meyerozyma caribbica UL5-1 and Pichia silvicola UL6-1

\begin{tabular}{lcc}
\hline \hline Carbon sources & $\begin{array}{c}\text { Meyerozyma } \\
\text { caribbica UL5-1 }\end{array}$ & $\begin{array}{c}\text { Pichia silvicola } \\
\text { UL6-1 }\end{array}$ \\
\hline D-glucose & $+^{*}$ & + \\
Fructose & + & + \\
Mannose & + & + \\
Maltose & - & - \\
D-galactoes & + & - \\
Sucrose & + & - \\
Lactose & - & - \\
Raffinose & + & - \\
Starch & - & - \\
Sorbitol & - & - \\
Cellobiose & - & + \\
\hline
\end{tabular}

${ }^{*}+$; Fermentable, -; not fermentable

\section{Mycological characteristics of the unrecorded yeasts}

The morphological and cultural characteristics of the two unrecorded yeasts are summarized in Table 1 and Fig. 1. The two unrecorded yeasts were both oval in shape 
Table 4. Physiological functionalities of unrecorded yeasts from Ulleungdo, Korea

\begin{tabular}{lcccc}
\hline \hline & \multicolumn{2}{c}{ Meyerozyma caribbica UL5-1 } & \multicolumn{2}{c}{ Pichia silvicola UL6-1 } \\
\cline { 2 - 5 } & Supernatant & Cell-free ext. & Supernatant & Cell-free ext. \\
\hline ACE $^{*}$ inhibitory activity (\%) & $84.2( \pm 0.5)$ & $29.4( \pm 0.8)$ & $82.6( \pm 0.7)$ & $14.9( \pm 0.7)$ \\
XOD inhibitory activity (\%) & n.d & $7.6( \pm 0.5)$ & n.d & $14.6( \pm 0.5)$ \\
SOD-like activity (\%) & n.d & n.d & n.d & n.d \\
Antioxidant activity (\%) & $14.9( \pm 0.6)$ & $2.1( \pm 0.1)$ & $12.0( \pm 0.1)$ & n.d \\
Q-Glucosidase inhibitory activity (\%) & n.d & $66.4( \pm 0.2)$ & n.d & $85.8( \pm 0.7)$ \\
Tyrosinase inhibitory activity (\%) & $19.5( \pm 0.2)$ & $19.9( \pm 0.2)$ & $28.4( \pm 0.5)$ & $7.4( \pm 0.1)$ \\
\hline
\end{tabular}

${ }^{*}$ ACE, Angiotensin I-converting enzyme; XOD, Xanthine oxidase; SOD, Superoxide dismutase.

${ }^{*}$ n.d; not detected.

did not form ascospores and pseudomycelia. Both grew well in YPD, yeast extract-malt extract (YM) and potatodextrose (PD) broth and also grew in vitamin-free medium. M. caribbica UL5-1 was found to be halophilic and thermotolerant, and grew well in $20 \% \mathrm{NaCl}-\mathrm{YPD}$ broth at $37^{\circ} \mathrm{C}$. Both yeasts were negative for urease activity.

We previously reported about a thermotolerant yeast isolated from wild flowers [14], traditional meju [6], and halotolerant yeasts from Korean fermented soy sauce, Doenjang and Gochujang [18].

We investigated the assimilation and fermentation of the two unrecorded yeasts on various carbon sources, using previously described methods [18] (Table 2 and 3). M. caribbica UL5-1 utilized several types of hexose, pentose and sugar alcohol such as D-glucose, D-galactose, D-maltose, $\mathrm{D}$-saccharose, $\mathrm{D}$-trehalose, $\mathrm{D}$-melezitose, $\mathrm{D}$-raffinose, D-cellobiose, D-xylose, L-arabinose, glycerol, 2-keto-D-gluconate, D-sorbitol, methyl- $\alpha$-D-glucopyranoside and $\mathrm{N}$ acetyl-glucosamine. However, it was not able to utilize Dlactose, xylitol, or inositol. Pichia silvicola UL6-1 utilized only D-glucose, D-galactose, D-trehalose, D-cellobiose, glycerol and D-sorbitol. Furthermore, M. caribbica UL5-1 fermented D-glucose, fructose, mannose, D-galactose, sucrose and raffinose, whereas $P$. silvicola UL6-1 fermented only D-glucose, fructose, mannose and cellobiose.

\section{Physiological functionalities of the unrecorded yeasts}

The physiological functionalities of the supernatants and cell-free extracts from the unrecorded yeasts were investigated (Table 4). The antihypertensive ACE inhibitory activities of supernatants from $M$. caribbica UL5-1 and Pichia silvicola UL6-1 were $84.2 \%$ and $82.6 \%$, respectively, approximately $50 \%$ higher than those of their cell-free extracts.

These results were higher than those of Saccharomyces cerevisiae KCTC 7904 (42.1\%)[13], Pichia anomala (31.0\%), Pichia anomala KCCM 11473 (72.0\%)[19], or Pleurotus cornucopiae (78.0\%)[20].

The anti-obesity $\alpha$-glucosidase inhibitory activity of cellfree extract from Pichia silvicola UL6-1 was also very high $85.8 \%$. These results were higher than those of Aspergillus oryzae N157-1 (48.3\%)[17] or Pichia burtonii (90.9\%)[3] isolated from Korean traditional fermented foods. Tyrosinase inhibitory activity and the other functionalities were either not detected or were very weak (15\%).

\section{Acknowledgements}

This study was funded by the project on survey and excavation of Korean indigenous species of NIBR under the Ministry of Environment, Republic of Korea.

\section{REFERENCES}

1. Jang IT, Kang MG, Na KC, Lee JS. Growth characteristics and physiological functionality of yeasts in pear marc extracts. Kor J Mycol 2011;39:170-3.

2. Jeong SC, Lee DH, Lee JS. Production and characterization of an anti-angiogenic agent from Saccharomyces cerevisiae K-7. J Microbiol Biotechnol 2006;16:1904-11.

3. Kim YH. Production and in-vivo anti-diabetic activity of $\alpha$ glucosidase inhibitor from Pichia burtonii Y257-7 [dissertation]. Daejeon (Korea): University of Paichai; 2013.

4. Lee JS, Yi SH, Kown SJ, Ahn C, Yoo JY. Enzyme activities and physiological functionality of yeasts from traditional Meju. Kor J Appl Microbiol Biotechnol 1997;25:448-53.

5. Kim JH, Lee DH, Jeong SC, Chung KS, Lee JS. Characterization of antihypertensive angiotensin I-converting enzyme inhibitor from Saccharomyces cerevisiae. J Microbiol Biotechnol 2004;14:1318-23.

6. Kim JH, Kim NM, Lee JS. Physiological characteristics and ethanol fermentation of thermotolerant yeast Saccharomyces cerevisiae OE-16 from traditional meju. Kor J Food Nutr 1999; 12:490-5. 
7. Kang MG, Hyun SH, Ryu JJ, Min JH, Kim HK, Lee JS. Note on newly isolated yeasts from wild flowers in Daejeon city, Korea. Kor J Mycol 2012;40:174-6.

8. Min JH, Hyun SH, Kang MG, Lee HB, Kim CM, Kim HK, Lee JS. Isolation and identification of yeasts from wild flowers of Daejeon city and Chungcheongnam-do in Korea. Kor J Mycol 2012;40:141-4.

9. Min JH, Ryu JJ, Kim HK, Lee JS. Isolation and identification of yeasts from wild flowers in Gyejoksan, Oseosan and Beakamsan of Korea. Kor J Mycol 2013;41:47-51.

10. Hyun SH, Lee HB, Kim CM, Lee JS. New records of yeasts from wild flowers in coast near areas and inland areas, Korea. Kor J Mycol 2013;41:74-80.

11. Min JH, Lee HB, Lee JS, Kim HK. Identification of yeasts isolated from wild flowers collected in coast areas of Korea based on the 26S rDNA sequences. Kor J Mycol 2013;41:18591.

12. Hyun SH, Mun HY, Lee HB, Kim HK, Lee JS. Isolation of yeasts from wild flowers in Gyonggi-do and Jeju island of Korea and production of anti-gout xanthine oxidase inhibitor. J Microbiol Biotechnol 2013;41:383-90.

13. Hyun SH, Min JH, Kim AR, Kim HK, Lee JS. Isolation and diversity of yeasts from wild flowers in Ulleungdo and Yokjido, Korea. Kor J Mycol 2014;42:28-33.

14. Hyun SH, Lee HB, Lee JS. Characteristics of unrecorded yeasts, Rhodosporidium fluviale, Rhodosporidium paludigenum, Candida sp. 80-J-3 and Kluyveromyces thermotolerans isolated from wild flowers in Korea. Kor J Mycol 2014;41:181-4.

15. Cushman DW, Cheung HS. Spectrophotometric assay and properties of the angiotensin-converting enzyme of rabbit lung. Biochem Pharmacol 1971;20:1637-48.

16. Kim JK, Cha WS, Park JH, Oh SL, Cho YJ, Chun SS, Choi C. Inhibition effect against tyrosinase of condensed tannins from Korean green tea. Kor J Food Sci Technol 1997; 29:173-7.

17. Kang MG, Yi SH and Lee JS. Production and characterization of a new $\alpha$-glucosidase inhibitory peptide from Aspergillus oryzae N159-1. Mycobiology 2013;41:149-54.

18. Lee JS, Choi YJ, Kwon SJ, Yoo JY, Chung DH. Screening and characterization of osmotolerant and gas-producing yeasts from traditional Doenjang and Kochujang. Food Biotechnol 1996;5:54-8.

19. Kim NM, So SH, Lee SG, Song JE, Seo DS, Lee JS. Physiological functionality and enzyme activity of biomass from Pichia anomala grown on ginseng-steaming effluent. Mycobiology 2008;36:148-51.

20. Jang JH, Jeong SC, Kim JH, Lee YH, Ju YC, Lee JS. Characterization of a new antihypertensive angiotensin I-converting enzyme inhibitory peptide from Pleurotus cornucopiae. Food Chem 2011;127:412-8. 